\title{
Increased Vascular Injury Reduces the Degree of Intimal Hyperplasia following Angioplasty in Rabbits
}

\author{
Per Fogelstrand $^{\mathrm{a}}$ Stefan Mellander ${ }^{\mathrm{b}}$ Erney Mattsson ${ }^{\mathrm{b}}$ \\ ${ }^{a}$ Department of Molecular and Clinical Medicine, Institute of Medicine, Sahlgrenska Academy at the University of \\ Gothenburg and bepartment of Vascular Surgery, Sahlgrenska University Hospital, Gothenburg, Sweden
}

\section{Key Words}

Neointima $\cdot$ Adventitia $\cdot$ Smooth muscle cells .

Angioplasty $\cdot$ Rabbit

\begin{abstract}
Background/Aims: Formation of intimal hyperplasia following angioplastic procedures can lead to complications, including restenosis and accelerated atherosclerosis. The vessel wall media is a main source of neointimal cells. However, evidence suggests that there are additional cell sources, such as the adventitia. Here we investigate whether an extensive loss of vascular smooth muscle cells (VSMCs) in the media results in less intimal hyperplasia or if there is compensatory cell recruitment from the adventitia. Methods: A balloon catheter was pulled through the rabbit carotid artery 4 times (major injury) or 2 times (minor injury). Adventitial cells were labeled with 5-bromo-2-deoxyuridine or PKH26. Results: The major injury, but not the minor injury, resulted in a complete loss of VSMCs in large parts of the media and significant leukocyte infiltration. The major injury resulted in less neointima compared with the minor injury. The thinnest neointima was seen at the most injured parts of the media in the major injury group. Cell-tracking experiments
\end{abstract}

showed that the media, but not the adventitia, served as a source of neointimal cells. Conclusion: An augmented angioplastic injury with extensive VSMC loss in rabbits reduced the degree of intimal hyperplasia. No compensatory recruitment of neointimal cells from the adventitia occurred.

Copyright $\odot 2011$ S. Karger AG, Basel

\section{Introduction}

The main interventional treatments for symptomatic atherosclerosis are bypass surgery and balloon angioplasty combined with stent implantation. However, $8-40 \%$ of the interventions fail within the first year due to restenosis, depending on the location and complexity of the atherosclerotic lesion and the procedure [1-3]. A major cause of restenosis is intimal hyperplasia, which is formed by accumulation of vascular smooth muscle cells (VSMCs) and deposition of extracellular matrix in the intimal vessel wall layer [4]. Intimal hyperplasia is also a substrate for lipoprotein retention leading to accelerated atherosclerosis, which is likely the cause of the rapid atherogenesis seen in vein grafts [5-7].

\section{KARGER}

Fax +4161306 1234 E-Mail karger@karger.ch www.karger.com (c) 2011 S. Karger AG, Basel

1018-1172/11/0484-0307\$38.00/0

Accessible online at:

www.karger.com/jvr
Dr. Per Fogelstrand

Wallenberg Laboratory, University of Gothenburg

Bruna Stråket 16

SE-413 45 Gothenburg (Sweden)

Tel. +46 31342 2210, Fax +46 3182 3762, E-Mail per.fogelstrand@wlab.gu.se 
Although the vessel wall media is a well-accepted source of intimal VSMCs, the adventitia is an additional potential cell source. However, it is not known under which conditions the adventitia contributes cells to the neointimal formation. For example, cell migration from the adventitia to the neointima might depend on the degree of vascular injury to the media. Apoptosis of VSMCs is observed in the media shortly after balloon injury [8], and after a severe vascular injury the media can become almost acellular $[9,10]$. Hence, an injury that induces neointimal formation can also deplete a main source of neointimal cells. In this situation, the adventitia might serve as an extra source of cells. Studies in the rat and pig have reported that more than $80 \%$ of the neointimal cells are derived from the adventitia following a severe balloon injury with major trauma to the media $[9,11]$. However, other studies have shown no adventitial contribution of neointimal cells $[12,13]$.

The aim of this study was to investigate whether a massive loss of VSMCs in the media results in less intimal hyperplasia or if there is compensatory recruitment of neointimal cells from the adventitia. We compared a major and a minor balloon injury in the rabbit carotid artery, where the major injury resulted in an extensive loss of medial VSMCs. We showed that the media was the main source of neointimal cells and that a severe balloon injury did not promote translocation of adventitial cells into the neointima. Instead, depletion of VSMCs in the media resulted in less intimal thickening, despite an increased inflammatory response. Hence, an increased magnitude of the angioplastic injury can, in certain circumstances, be beneficial in reducing the formation of intimal hyperplasia.

\section{Methods}

\section{Animals, Surgery and Cell Labeling}

All procedures were approved by the Animal Ethics Committee at the University of Gothenburg. Male New Zealand White rabbits (weight: $2.9-3.5 \mathrm{~kg}$ ) were pre-medicated with midazolam $1 \mathrm{mg} / \mathrm{kg}$ intramuscularly (Dormicum ${ }^{\circledR}$; Hoffmann-La Roche AG, Basel, Switzerland) and 10 min later anesthetized with fentanyl/ fluanisone $0.2 \mathrm{ml} / \mathrm{kg}$ intramuscularly $\left(\right.$ Hypnorm $^{\circledR}$; Janssen Pharmaceutica, Beerse, Belgium). To maintain anesthesia, an additional dose of $0.06 \mathrm{ml} / \mathrm{kg}$ fentanyl/fluanisone was given after 40 min. Balloon injury to the carotid artery was induced using a 3-french Fogarty embolectomy catheter (Edwards Laboratories, Santa Ana, Calif., USA) as earlier described [14]. The catheter was drawn through the common carotid artery either 4 times to induce major injury or 2 times to induce minor injury. Animals with acute thrombosis at the time of surgery (secondary to medial dissection) were excluded.
To pulse-label proliferating cells with 5-bromo-2-deoxyuridine (BrdU), rabbits were injected with BrdU at 12 and $24 \mathrm{~h}(\mathrm{n}=$ $12)$ or at 48 and $72 \mathrm{~h}(\mathrm{n}=12)$ after balloon injury $(60 \mathrm{mg} / \mathrm{kg}$ subcutaneous; Roche Diagnostics). To label adventitial cells with PKH26 [12], the carotid artery was dissected free from its surrounding tissue immediately after the balloon injury. A $2-\mathrm{cm}$ segment of the vessel was bathed for $20 \mathrm{~min}$ in $1 \mathrm{ml}$ of $0.1 \mu \mathrm{mol} / 1$ PKH26 (Sigma, Schnelldorf, Germany). The artery was washed with saline solution, and the wound was closed.

\section{Histology}

For PKH26 analyses, the rabbits were killed at day 14, the vessels were perfused with saline and samples of the carotid arteries were imbedded in OCT compound and snap frozen in liquid nitrogen. Cryosections $(8 \mu \mathrm{m})$ were stored in dark boxes at $-80^{\circ} \mathrm{C}$. Sections of PKH26-labeled tissues were nuclear stained with $4^{\prime}, 6$ diamidino-2-phenylindole (DAPI) and analyzed using a fluorescence microscope.

For all other analyses the rabbits were re-anesthetized at indicated times and pressure perfused with saline followed by $4 \%$ formalin as previously described [14]. The mid-section of the carotid artery was collected and further fixed in formalin for $4 \mathrm{~h}$, dehydrated in ethanol followed by xylene, and finally embedded in paraffin. Transverse sections of $5 \mu \mathrm{m}$ were cut into slides. The specimens were de-waxed, and pre-treated with proteinase $\mathrm{K}(300$ $\mu \mathrm{g} / \mathrm{ml}, 5 \mathrm{~min})$, hydrogen peroxide (3\%, $5 \mathrm{~min})$ and dry-milk powder solution (5\%, 15 min; Semper, Sundbyberg, Sweden). The following mouse monoclonal antibodies were used: anti-BrdU (ready-to-use super-sensitive mouse anti-BrdU IIB5; BioGenex, San Ramon, Calif., USA), mouse anti-human smooth muscle $\alpha$ actin (1:500; DAKO, Glostrup, Denmark) and mouse anti-rabbit CD18 (1:500; Acris Antibodies, Hiddenhausen, Germany). The specimens were incubated with primary antibodies at $+4^{\circ} \mathrm{C}$ overnight, followed by $30 \mathrm{~min}$ with a secondary antibody conjugated with horseradish peroxidase (Envision; DAKO). Diaminobenzidine (DAB kit; DAKO) was used for visualization. Negative controls for BrdU staining were taken from balloon-injured rabbits that had not been treated with BrdU. For $\alpha$-actin and CD18, nonimmune mouse IgG primary antibodies were used as negative controls.

Morphometric Analyses and Leukocyte Counting

The total number of nuclei in the media $2 \mathrm{~h}$ after balloon injury was counted manually in hematoxylin-stained paraffin sections. Fragmented nuclei (apoptotic) were excluded. The area of brown $\alpha$-actin staining in the media 4 days after injury and the neointimal area and thickness 14 days after injury were measured with the Kontron Electronic image analyzing system (KS400 version 3.0; Carl Zeiss, Göttingen, Germany). The total number of nuclei in the neointima at day 14 was counted manually in DAPIstained paraffin sections. CD18-positive leukocytes in the adventitia and media 4 days after injury were counted manually. Because of difficulties in distinguishing the adventitia from the perivascular tissue, only adventitial leukocytes in contact with the external elastic lamina were counted.

\section{Statistics}

Data were analyzed with two-tailed Student's t test and twoway ANOVA with Bonferonni post hoc test using GraphPad Prism 5 (GraphPad Software). 

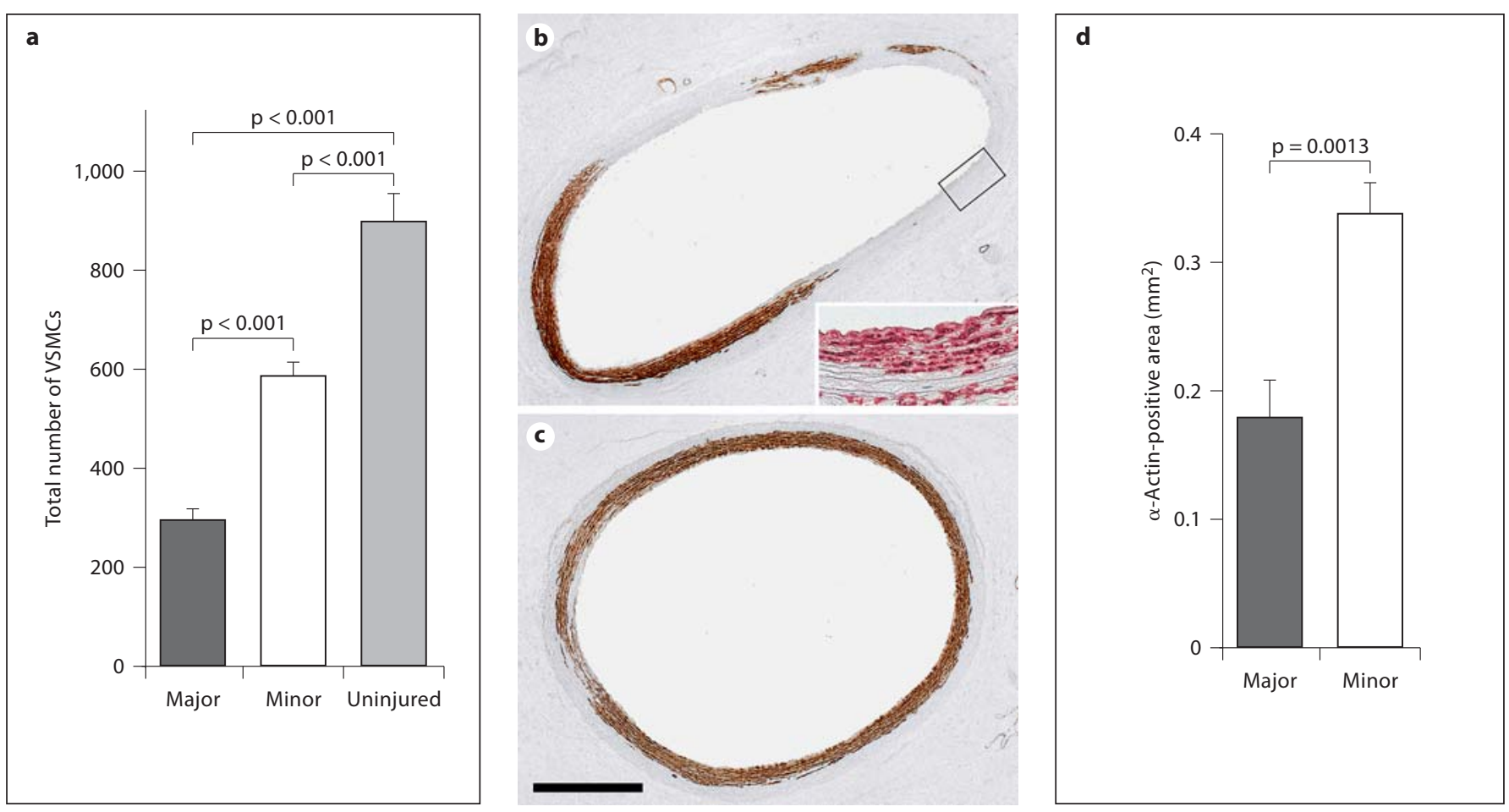

Fig. 1. VSMC loss in the media following a major and a minor balloon injury to the rabbit carotid artery. a Total number of cells in the media $2 \mathrm{~h}$ after a major or a minor balloon injury or no injury (uninjured). Tissue sections were nuclear stained with hematoxylin and all intact nuclei in the media were counted. Results are shown as means \pm SEM. $n=6$ in each group. $\mathbf{b} \alpha$-Actin expression (brown staining) 4 days after a major balloon injury.
The insert is a serial section showing CD18-positive cells (leukocytes) in the $\alpha$-actin-negative area outlined in the carotid artery. c $\alpha$-Actin expression (brown staining) 4 days after a minor balloon injury. Scale bar $=0.5 \mathrm{~mm}$. $\mathbf{d}$ The area of brown $\alpha$-actin staining in the media 4 days after a major $(n=7)$ and a minor injury $(n=8)$. Results are shown as means \pm SEM.

\section{Results}

\section{Extensive VSMC Loss following a Major Balloon Injury}

We induced a major or minor balloon injury to the common carotid artery in rabbits. Two hours after injury, the total cell number in the media (VSMCs) was significantly less in the major injury group compared with the minor injury group (fig. 1a). At day 4 after the major injury, large $\alpha$-actin-negative areas were seen in the media, and these areas were mainly repopulated with leukocytes (fig. 1b). At day 4 after the minor injury, some loss of $\alpha$ actin could be seen, but a continuum of $\alpha$-actin-positive cells was present around the medial circumference (fig. 1c). The total $\alpha$-actin-positive area at day 4 was significantly less following the major injury compared with the minor injury (fig. 1d).

Increased Vascular Injury Reduces Intimal Hyperaplasia

\section{Increased Leukocyte Infiltration and Reduced Neointimal Formation following a Major Balloon Injury}

At day 4, there were significantly more leukocytes (CD18-positive cells) in both the media and the adventitia after the major injury compared with the minor injury, and the difference in leukocyte count was more pronounced in the media (fig. 2a). The medial leukocytes were mainly associated to areas of VSMC loss (fig. 1b, insert), while the adventitial leukocytes were more evenly distributed around the circumference (data not shown).

At day 14 after injury, the neointimal area in the major injury group was significantly reduced compared with the minor injury group (fig. 2b). Detailed studies within the major injury group revealed that the thinnest neointima was formed at the most injured parts of the vessel. These areas were characterized by low levels of smooth muscle $\alpha$-actin $\left(\alpha\right.$-actin $\left.{ }^{\text {low }}\right)$, both in the media and the neointima (fig. 2c). At the less injured areas within the 

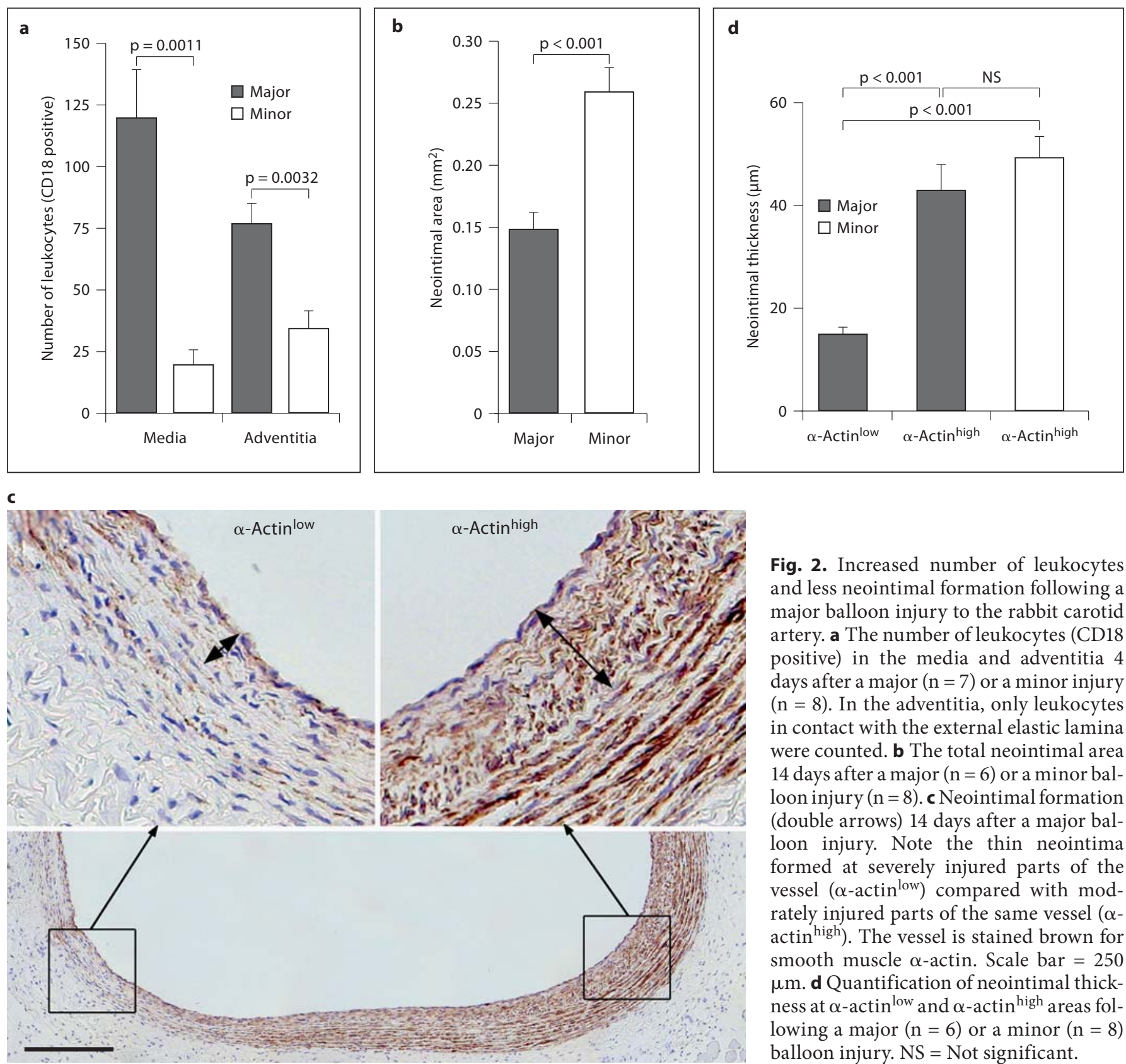

Fig. 2. Increased number of leukocytes and less neointimal formation following a major balloon injury to the rabbit carotid artery. a The number of leukocytes (CD18 positive) in the media and adventitia 4 days after a major $(n=7)$ or a minor injury $(n=8)$. In the adventitia, only leukocytes in contact with the external elastic lamina were counted. $\mathbf{b}$ The total neointimal area 14 days after a major $(n=6)$ or a minor balloon injury $(\mathrm{n}=8)$. c Neointimal formation (double arrows) 14 days after a major balloon injury. Note the thin neointima formed at severely injured parts of the vessel $\left(\alpha\right.$-actin $\left.{ }^{\text {low }}\right)$ compared with modrately injured parts of the same vessel $(\alpha-$ $\operatorname{actin}^{\text {high }}$ ). The vessel is stained brown for smooth muscle $\alpha$-actin. Scale bar $=250$ $\mu \mathrm{m}$. d Quantification of neointimal thickness at $\alpha$-actin ${ }^{\text {low }}$ and $\alpha$-actin ${ }^{\text {high }}$ areas following a major $(n=6)$ or a minor $(n=8)$ balloon injury. NS = Not significant.

major injury group, characterized by high levels of smooth muscle $\alpha$-actin $\left(\alpha\right.$-actin $\left.{ }^{\text {high }}\right)$, the neointima was almost 3 times thicker (fig. 2c, d). Furthermore, the neointimal thickness at the $\alpha$-actin ${ }^{\text {high }}$ areas in the major injury group was of similar size as the neointimal thickness in the minor injury group (fig. $2 \mathrm{~d}$ ). Thus, the reduced neointima following the major balloon injury was caused by a very limited neointima formation at $\alpha$ actin $^{\text {low }}$ areas.
The difference in neointimal area between groups can depend on a difference in cell number, cell size or extracellular matrix. The number of intimal cells did not differ between groups (fig. 3a), because of a higher cell density following the major injury compared with the minor injury (fig. 3b). Within the major injury group the cell density was similar between $\alpha$-actin ${ }^{\text {low }}$ and $\alpha$-actin ${ }^{\text {high }}$ areas (fig. 3c). Thus, the major injury resulted in an overall increased cell density due to either less extracellular matrix 

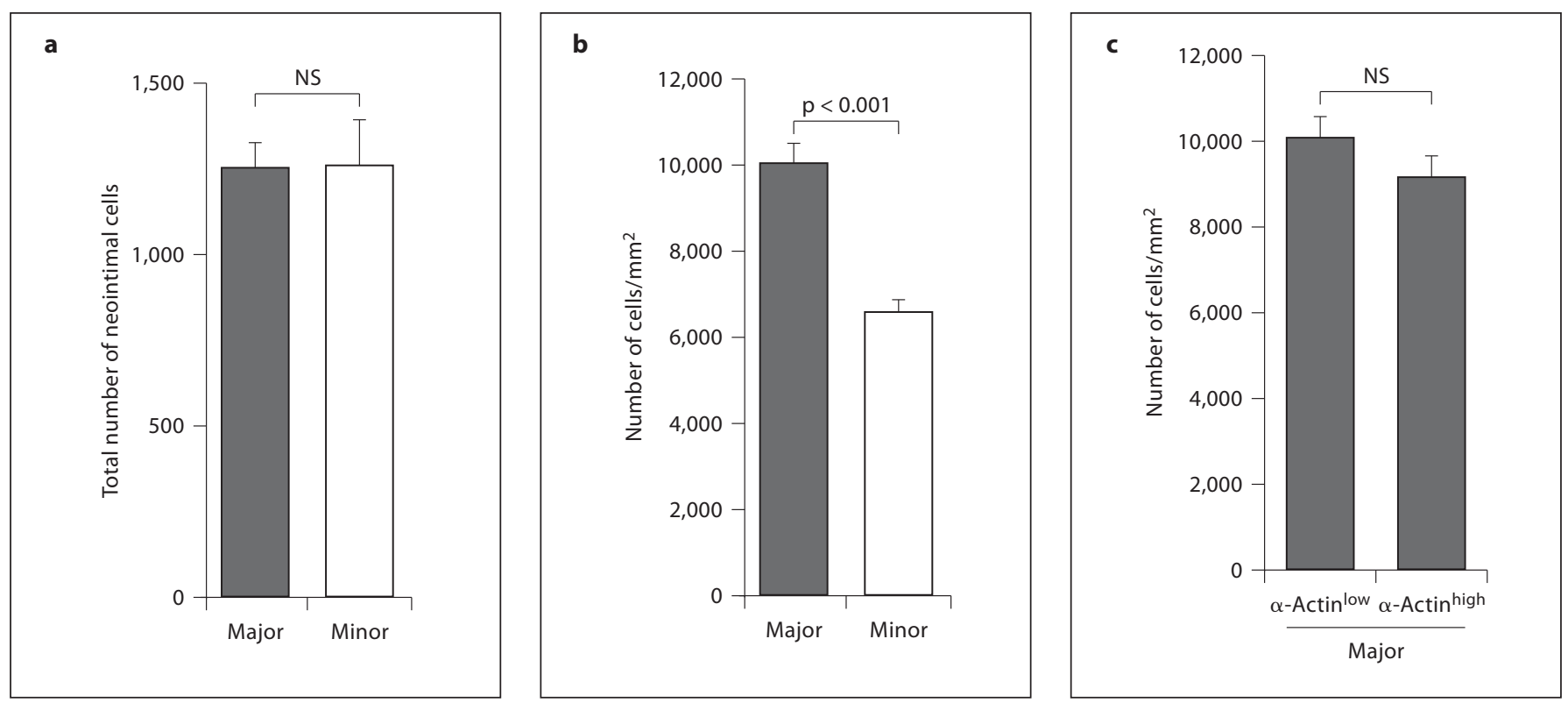

Fig. 3. Number of cells and cell density in the neointima 14 days following a major $(n=6)$ and a minor balloon injury $(n=8)$ to the rabbit carotid artery. a Total number of neointimal cells in the major injury group and the minor injury group. $\mathbf{b}$ Cell density in the major injury group and the minor injury group. c Cell density at $\alpha-$ actin $^{\text {low }}$ and $\alpha$-actin ${ }^{\text {high }}$ areas within the major injury group. NS = Not significant.

and/or smaller cells. However, the higher cell density in the major injury group could not explain the limited neointimal formation in $\alpha$-actin ${ }^{\text {low }}$ areas. At those areas less neointimal cells were the main factor.

\section{Neointimal Cells Are Recruited from the Media but \\ Not the Adventitia}

Because proliferation in the adventitia starts earlier than proliferation in the media, it is possible to selectively label adventitial cells with $\operatorname{BrdU}[9,11]$. To assess if cells migrated from the adventitia into the neointima in the present study, we injected rabbits with BrdU 12 and $24 \mathrm{~h}$ after balloon injury. Samples taken at day 4 after the major and minor balloon injuries showed that this BrdU pulse-labeling was effective and selective for the adventitia (fig. 4a, b). At day 14, no BrdU-positive cells were detected in the neointima in either group, although cells in the adventitia still showed strong staining for BrdU (fig. 4c, d). Thus, extensive loss of medial VSMCs did not stimulate translocation of BrdU-labeled cells from the adventitia to the neointima.

To assess if cells migrated from the media into the neointima, we injected BrdU 48 and $72 \mathrm{~h}$ after injury. With this labeling protocol, proliferating cells were labeled in both the media and the adventitia, as shown by samples taken 4 days after injuries (fig. 4e, f). At day 14, BrdUpositive cells were present in the neointima after both the major and the minor injuries (fig. 4g, h). Since selectively labeled adventitial cells did not translocate to the neointima (fig. 4c, d), these data strongly suggest that the media was a source of neointimal cells.

As a complement to the BrdU-labeling protocol, we applied the fluorescent cell membrane dye PKH26 to carotid arteries immediately after the balloon injury. This treatment labels both proliferating and nonproliferating cells in the adventitia but does not reach cells in the media [12]. At 14 days after injury, PKH26-labeled cells were found in the adventitia in both the major and minor injury groups, but no labeled cells were found in the neointima (fig. 5a, b). These PKH26 data provide further evidence to show that the adventitia was not a source of neointimal cells.

\section{Discussion}

In the present study, we analyzed the formation of intimal hyperplasia following a major and a minor balloon injury in the rabbit carotid artery. The major balloon injury resulted in an early extensive loss of medial VSMCs, 


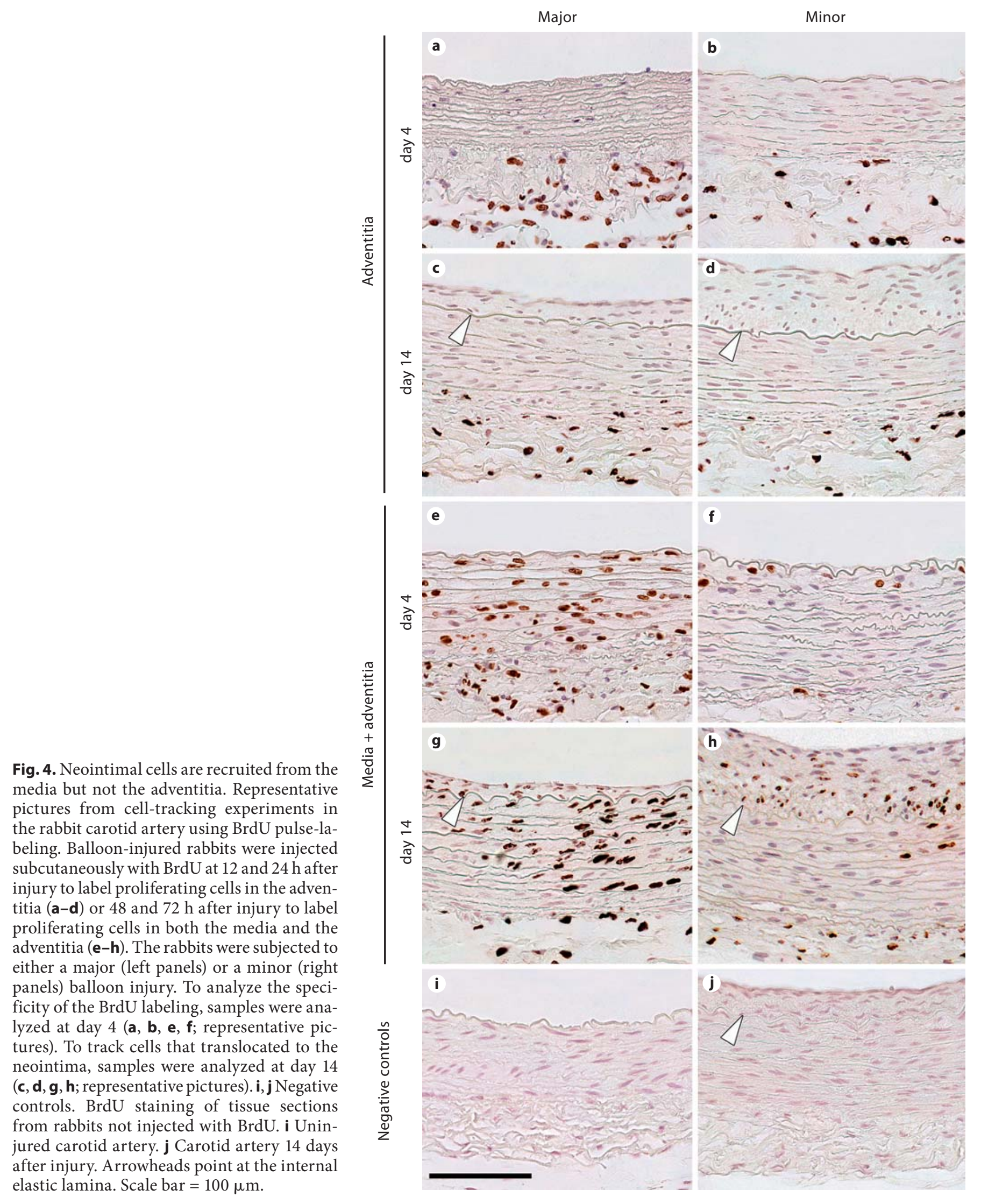

Fig. 4. Neointimal cells are recruited from the media but not the adventitia. Representative the rabbit beling. Balloon-injured rabbits were injected after injury. Arrowheads point at the internal elastic lamina. Scale bar $=100 \mu \mathrm{m}$. 
which is in agreement with earlier studies showing a very rapid cell death due to apoptosis following balloon injury to the carotid artery in rat and rabbit $[8,15]$. The major balloon injury also caused an increased inflammatory response. Surprisingly, the outcome of the major injury was less intimal hyperplasia compared with the minor injury. The reduced neointima was completely restricted to the areas of extensive VSMC loss following the major balloon injury, suggesting that the medial VSMCs are the major source of cells during the neointimal formation. This notion was supported by cell-tracking experiments that showed that the media, but not the adventitia, served as a source of neointimal cells, both after the major and the minor vascular injury. Thus, severe vascular injury with a massive loss of medial VSMCs did not promote translocation of adventitial cells to the neointima in the rabbit carotid artery.

Inflammation is a central event in neointimal formation $[16,17]$. Consequently, targeting the inflammatory response is a potential strategy to block neointimal formation and restenosis $[16,17]$. In the present study, the major balloon injury caused an expected increase in the inflammatory response compared with the minor injury. Despite this increase, the major injury caused a reduction in the neointimal formation. The reduction of the neointima was seen at areas of early extensive VSMC loss, suggesting that the presence of medial VSMCs was a stronger determinant of the neointimal formation than the inflammatory response.

Our cell-tracking experiments supported the early theories stating that the media is the main source of neointimal cells $[18,19]$. However, the origin of neointimal cells is still under debate. Several cell-tracking studies have examined the adventitia as a source of intimal VSMCs. Some of these studies show no contribution of adventitial cells $[12,13]$, whereas others show a significant contribution of adventitial cells to the neointima [9, 11, 20-23]. An explanation for these contradictory results might be that the adventitial participation depends on the degree of vascular injury. We hypothesized that the adventitia might serve as an extra source of neointimal cells following severe vascular injury when there is an extensive loss of medial VSMCs and therefore no medial VSMCs are available for the neointimal formation. However, our data show no compensatory recruitment of cells from the adventitia to the neointima. Hence, such a graded adventitial response does not seem to exist in the rabbit carotid artery.

Translocation of adventitial cells into the neointima has been reported in pig and rat $[9,11,20-23]$. It is pos-
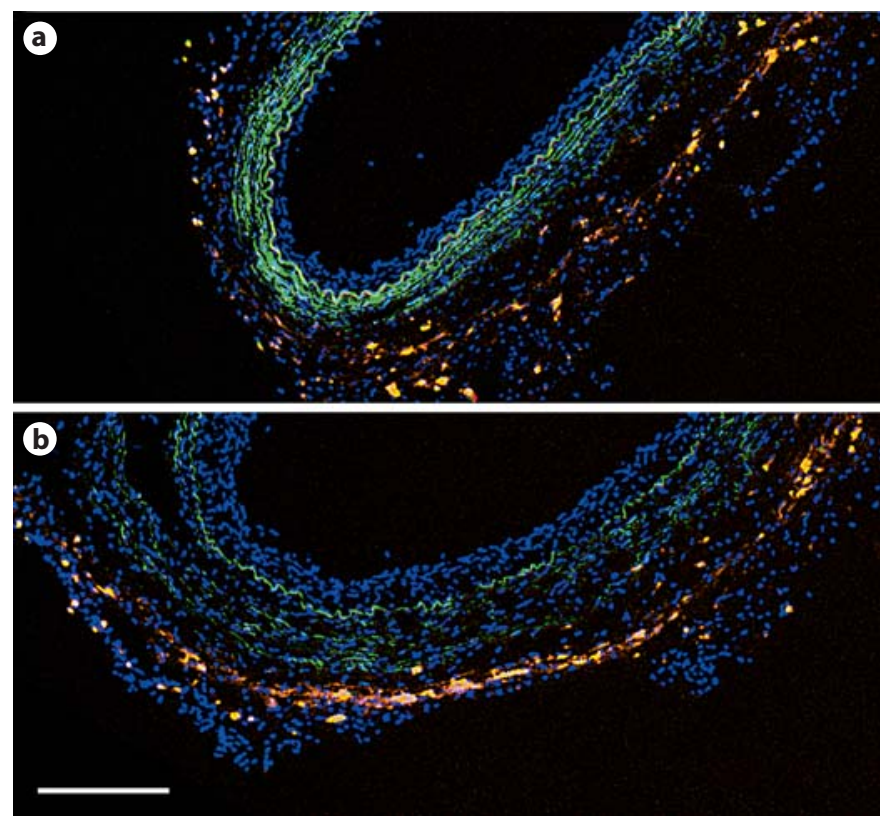

Fig. 5. PKH26-labeled adventitial cells do not translocate into the neointima. Representative pictures from cell-tracking experiments in the rabbit carotid artery using the fluorescent dye PKH26. PKH26 was locally applied around the carotid artery to selectively label cells in the adventitia immediately after a major (a) or a minor (b) balloon injury. The vessels were collected at day 14. PKH26-labeled cells (red) were found in the adventitia, but not in the media or the neointima. Nuclei are stained blue with DAPI. $\mathrm{n}=2$ rabbits in each group. Scale bar $=200 \mu \mathrm{m}$.

sible that the opposite results in the present study are due to species differences. In pig coronary arteries, a translocation of adventitial cells is seen following severe balloon traumas with medial dissection. An injury of this kind creates a direct connection between the adventitia and the lumen. This means that adventitial cells do not need to pass the media to reach the neointima. In rat, the media usually do not break following balloon injury, but there is a clear difference in the adventitial response compared with rabbit. Already $4 \mathrm{~h}$ after rat carotid injury a vast number of cells proliferate in the adventitia [9]. At this early time point we could not detect any proliferation at all in the rabbit carotid artery (data not shown). The pronounced adventitial reaction in rat might be a result of a thinner media, which for example might facilitate migratory and growth-stimulating factors from plasma, platelets and leukocytes to reach the adventitial compartment more easily and thereby provide a stronger stimulus for adventitial cells to proliferate and migrate towards the lumen. 
To track the adventitial cells, we used two different labeling substrates, BrdU and PKH26. Both techniques labeled a substantial number of adventitial cells, but we did not detect any translocation of the labeled cells to the neointima. The signal from both BrdU and PKH26 go halves after each round of mitosis and therefore rapidly dividing cells might eventually escape detection. However, BrdU has previously been used successfully both in rat and pig to track adventitial cell migration into the neointima [9, 11]. A limitation of using $\mathrm{BrdU}$ is that nonproliferating cells, which might potentially migrate into the neointima, are not detected. Therefore, we also used PKH26, which labels both proliferating and nonproliferating adventitial cells, and showed that PKH26-labeled cells were not detected in the neointima either. Together, these two labeling techniques provide strong evidence to show that adventitial cells did not translocate into the neointima. However, we do not exclude that the adventitia might influence the neointimal formation by release of cytokines, growth factors and reactive oxygen species, for example [24].

Although the neointima was greatly reduced at areas of severe vascular injury in the major injury group in our study, a few neointimal cells were present and most of these cells expressed smooth muscle $\alpha$-actin. One possibility is that these intimal VSMCs migrated laterally from less injured areas. Alternatively, these cells were derived from the blood. Bone marrow-derived VSMCs (or, more accurately, smooth muscle cell-like cells) have been detected in the rat balloon-injury model and in different mouse models of intimal thickening [25-27].

A main finding in the present study is that depletion of a single source of intimal cells was sufficient to dra- matically reduce the neointimal formation in the rabbit. In humans, it is not known which cell sources are important for the formation of intimal hyperplasia. The available cell sources might vary depending on the treated vascular bed (for example peripheral artery, coronary artery or carotid artery) and/or the chosen procedure (for example balloon angioplasty, atherectomy, bypass surgery with vein grafts, arteries or prosthetic grafts). Importantly, our data imply that the available cell sources are a major determinant of the postangioplastic healing process and therefore the approach used to avoid restenosis/graft stenosis should be adjusted according to the location and type of vascular intervention.

In conclusion, we showed that the media, but not the adventitia, contributed neointimal cells to the rabbit carotid artery following balloon injury. Hence, an extensive loss of medial VSMCs did not promote migration of adventitial cells into the neointima. Instead, VSMC depletion in the media was associated with less intimal thickening, most likely due to a shortage of cells for the neointimal formation. Thus, an increased magnitude of the angioplastic injury might, under certain circumstances, be beneficial in reducing the degree of intimal hyperplasia.

\section{Acknowledgments}

We thank Anna Hallén and Maria Heyden for excellent technical support. This work was supported by grants from the Sahlgrenska University Hospital and from the Swedish Medical Research Council (2001-6502).

\section{References}

1 Mwipatayi BP, Hockings A, Hofmann M, Garbowski M, Sieunarine K: Balloon angioplasty compared with stenting for treatment of femoropopliteal occlusive disease: A meta-analysis. J Vasc Surg 2008;47:461-469.

$\checkmark 2$ Ramcharitar S, Gaster AL, Daemen J, Serruys P: Drug-eluting stents, restenosis and revascularization. Herz 2007;32:287-295.

-3 Schillinger M, Mlekusch W, Haumer M, Sabeti S, Ahmadi R, Minar E: Angioplasty and elective stenting of de novo versus recurrent femoropopliteal lesions: 1-year follow-up. J Endovasc Ther 2003;10:288-297.

$\checkmark 4$ Davies MG, Hagen PO: Pathobiology of intimal hyperplasia. Br J Surg 1994;81:12541269.
5 Williams KJ, Tabas I: The response-to-retention hypothesis of early atherogenesis. Arterioscler Thromb Vasc Biol 1995;15:551-561.

6 Barboriak JJ, Pintar K, Korns ME: Atherosclerosis in aortocoronary vein grafts. Lancet 1974;2:621-624.

7 Kalan JM, Roberts WC: Morphologic findings in saphenous veins used as coronary arterial bypass conduits for longer than 1 year: necropsy analysis of 53 patients, 123 saphenous veins, and 1,865 five-millimeter segments of veins. Am Heart J 1990;119:11641184.

8 Perlman H, Maillard L, Krasinski K, Walsh $\mathrm{K}$ : Evidence for the rapid onset of apoptosis in medial smooth muscle cells after balloon injury. Circulation 1997;95:981-987. $\checkmark 9$ Couffinhal T, Dufourcq P, Jaspard B, Daret D, Allieres C, Alzieu P, Serre P, Bonnet J, Duplaa $C$ : Kinetics of adventitial repair in the rat carotid model. Coron Artery Dis 2001;12: 635-648.

10 West JL, Hubbell JA: Separation of the arterial wall from blood contact using hydrogel barriers reduces intimal thickening after balloon injury in the rat: the roles of medial and luminal factors in arterial healing. Proc Natl Acad Sci USA 1996;93:13188-13193.

$\checkmark 11$ Shi Y, O’Brien JE, Fard A, Mannion JD, Wang D, Zalewski A: Adventitial myofibroblasts contribute to neointimal formation in injured porcine coronary arteries. Circulation 1996;94:1655-1664. 
-12 De Leon H, Ollerenshaw JD, Griendling KK, Wilcox JN: Adventitial cells do not contribute to neointimal mass after balloon angioplasty of the rat common carotid artery. Circulation 2001;104:1591-1593.

- 13 Faggin E, Puato M, Zardo L, Franch R, Millino C, Sarinella F, Pauletto P, Sartore S, Chiavegato A: Smooth muscle-specific sm 22 protein is expressed in the adventitial cells of balloon-injured rabbit carotid artery. Arterioscler Thromb Vasc Biol 1999;19:13931404.

14 Fogelstrand P, Risberg B, Mattsson E: External collar inhibits balloon-induced intimal hyperplasia in rabbits. J Vasc Res 2002;39: 361-367.

15 Pollman MJ, Hall JL, Gibbons GH: Determinants of vascular smooth muscle cell apoptosis after balloon angioplasty injury. Influence of redox state and cell phenotype. Circ Res 1999;84:113-121.

-16 Wainwright CL, Miller AM, Wadsworth RM: Inflammation as a key event in the development of neointima following vascular balloon injury. Clin Exp Pharmacol Physiol 2001;28:891-895.
7 Toutouzas K, Colombo A, Stefanadis C: Inflammation and restenosis after percutaneous coronary interventions. Eur Heart J 2004;25:1679-1687.

18 Hassler O: The origin of the cells constituting arterial intima thickening. An experimental autoradiographic study with the use of H3-thymidine. Lab Invest 1970;22:286293.

19 Clowes AW, Reidy MA, Clowes MM: Kinetics of cellular proliferation after arterial injury. I. Smooth muscle growth in the absence of endothelium. Lab Invest 1983;49:327-333.

20 Shi Y, O’Brien JE, Jr., Mannion JD, Morrison RC, Chung W, Fard A, Zalewski A: Remodeling of autologous saphenous vein grafts. The role of perivascular myofibroblasts. Circulation 1997;95:2684-2693.

-21 Li G, Chen SJ, Oparil S, Chen YF, Thompson JA: Direct in vivo evidence demonstrating neointimal migration of adventitial fibroblasts after balloon injury of rat carotid arteries. Circulation 2000;101:1362-1365.

22 Siow RC, Mallawaarachchi CM, Weissberg PL: Migration of adventitial myofibroblasts following vascular balloon injury: insights from in vivo gene transfer to rat carotid arteries. Cardiovasc Res 2003;59:212-221.
23 Tomas JJ, Stark VE, Kim JL, Wolff RA, Hullett DA, Warner TF, Hoch JR: $\beta$-Galactosidase-tagged adventitial myofibroblasts tracked to the neointima in healing rat vein grafts. J Vasc Res 2003;40:266-275.

24 Siow RC, Churchman AT: Adventitial growth factor signalling and vascular remodelling: potential of perivascular gene transfer from the outside-in. Cardiovasc Res 2007;75:659-668.

25 Han CI, Campbell GR, Campbell JH: Circulating bone marrow cells can contribute to neointimal formation. J Vasc Res 2001;38: 113-119.

26 Religa P, Bojakowski K, Maksymowicz M, Bojakowska M, Sirsjo A, Gaciong Z, Olszewski W, Hedin U, Thyberg J: Smoothmuscle progenitor cells of bone marrow origin contribute to the development of neointimal thickenings in rat aortic allografts and injured rat carotid arteries. Transplantation 2002;74:1310-1315.

-27 Tanaka K, Sata M, Hirata Y, Nagai R: Diverse contribution of bone marrow cells to neointimal hyperplasia after mechanical vascular injuries. Circ Res 2003;93:783-790. 